\title{
Formal Women-only Networks Literature Review and Propositions
}

\author{
Villesèche, Florence; Josserand, Emmanuel
}

Document Version

Accepted author manuscript

Published in:

Personnel Review

DOI:

10.1108/PR-03-2015-0074

Publication date:

2017

License

Unspecified

Citation for published version (APA):

Villesèche, F., \& Josserand, E. (2017). Formal Women-only Networks: Literature Review and Propositions.

Personnel Review, 46(5), 1004-1018. https://doi.org/10.1108/PR-03-2015-0074

Link to publication in CBS Research Portal

\section{General rights}

Copyright and moral rights for the publications made accessible in the public portal are retained by the authors and/or other copyright owners and it is a condition of accessing publications that users recognise and abide by the legal requirements associated with these rights.

Take down policy

If you believe that this document breaches copyright please contact us (research.lib@cbs.dk) providing details, and we will remove access to the work immediately and investigate your claim. 


\section{Formal Women-only Networks: Literature Review and Propositions}

Florence Villesèche and Emmanuel Josserand

Journal article (Accepted manuscript)

CITE: Formal Women-only Networks : Literature Review and Propositions. / Villesèche, Florence; Josserand, Emmanuel. In: Personne/ Review, Vol. 46, No. 5, 2017, p. 1004-1018.

This article is [C Emerald Group Publishing and permission has been granted for this version to appear here: https://research.cbs.dk/en/publications/formal-women-only-networks-literature-review-and-propositions. Emerald does not grant permission for this article to be further copied/distributed or hosted elsewhere without the express permission from Emerald Group Publishing Limited.

DOI: 10.1108/PR-03-2015-0074

Uploaded to CBS Research Portal: January 2019 


\section{Formal Women-Only Networks: Literature review and propositions}

\section{Introduction}

Prior research has established that women's ability to use informal networking for career development is limited (Dries and Pepermans, 2007; Wilson, 1991). Women in business thus enjoy less social capital than men, which makes it difficult for them to develop connections and access the linked resources (Gamba and Kleiner, 2001; Groysberg and Bell, 2013). This contributes to the persistence of gendered career paths (Wilson, 1998) and a numerical gender imbalance continues to prevail, especially at higher hierarchical levels. To date, the academic literature has paid significantly less attention to formal networks than to informal networking opportunities for individuals, and the usefulness and importance of formal networks in general is still downplayed (Lawton-Smith et al., 2012). Accordingly, formal women-only networks (WONs) have been under-studied (Miller et al., 2007) even though they are in fact a growing phenomenon (Durbin, 2011) both inside firms and as independent undertakings. We thus lack a clear theoretical and empirical understanding of how formal WONs can help counter the difficulties that women experience in using informal networking opportunities as efficiently as men. In this article, we propose to review the emerging literature on formal WONs and develop propositions about how internal and external networks of this type can yield benefits for members, organisations and the wider social group of women in management and leadership positions.

\section{Networks, networking and gender differences}

A growing body of literature shows how networks and networking in general can be advantageous for individuals; this is often encapsulated in the concept of social capital, that is to say 'the aggregate of present or potential resources which are linked to the possession of a durable network of more or less institutionalized relationships of mutual acquaintances and 
recognition' (Bourdieu, 1986, p. 246). Networking has been deemed critical for the development of managerial careers (Forret and Dougherty, 2004; Rasdi et al., 2013), which encompasses elements such as taking on more responsibility or being offered a new challenge (Wolf and Moser, 2009). Individuals with valuable network ties are more likely to be offered better jobs (Lin and Dumin, 1986; McGuire, 2000), secure promotions (Forret and Dougherty, 2004; Burt 1998) and be selected for sought-after international appointments (Linehan, 2001). Furthermore, increased visibility achieved through networking can lead to higher salaries (Forret and Dougherty, 2004; Rasdi et al., 2013; Wolf and Moser, 2009). One's network is also an especially important factor in reaching the highest hierarchical levels of organisations (Kogut et al., 2014). In sum, networking and access to resources through networks are pivotal for career development.

However, the literature shows that women see a lower return on networking activities than men and thus enjoy weaker social capital, in particular regarding career resources (Burt, 1998; Forret and Dougherty, 2004). One explanation for this is that the most influential business networks are informal, male-dominated and difficult to access for women (Gamba and Kleiner, 2001; Groysberg and Bell, 2013; Singh et al., 2006). More specifically, the literature often refers to the difficulties women encounter when trying to enter 'old boys' networks', or networks composed of powerful males (Gamba and Kleiner, 2001; Groysberg and Bell, 2013). These high-status networks are social structures through which existing gendered power relations are reproduced and maintained (Acker, 2006; Timberlake, 2005). An old boys' network can thus be seen as a 'gateway network that ultimately controls resources' (Durbin, 2011, p. 91). The difficulties in question can be linked to the concept of 'homophily', that is, the notion that people tend to network with those perceived as being highly similar to them (McPherson et al., 2001). As shown by Burt (1998) in a study exploring the relationship between network composition and early promotion, women's limited access to often male- 
only informal networks with a high degree of instrumental potential means they are less likely to be promoted.

Another explanation relates to the structure of women's networks: women's informal networks tend to involve more relatives and friends, while men report more professionally oriented ties (Dawson et al., 2011). Furthermore, Ibarra's seminal work (1992, 1993a) suggests that, for reasons relating to general social structures, women are not seen as holding positions in networks of social relations that make them attractive to others. This limits their opportunities to develop new ties (Brass and Burkhardt, 1993; Ibarra, 1993b), and especially ties with individuals who could provide career-related support (Ibarra, 1992, 1993b). Time constraints are yet another explanation: domestic and family-related responsibilities are still shouldered more widely by women than by men, which limits the time available for networking activities outside regular working hours (Linehan, 2001; Sharafizad, 2011).

\section{Formal women-only business networks}

To mitigate the limitations faced in informal networking, women tend to participate more in formal networks than in informal ones, unlike men (Durbin, 2011), and list gender-homophile networks as a useful type of network more frequently than men (Dawson et al., 2011). However, the phenomenon of formal WONs is both under-studied and under-theorised, despite the fact that such networks have been deemed a complement or alternative to making often fruitless efforts to enter male-dominated informal networks (Hersby et al., 2009).

Inside firms, such networks have existed for more than 30 years (Donnellon and Langowitz, 2009). However, academic interest in such networks is more recent, and scholars have referred to them under various labels, such as 'corporate women's networks' (e.g. AvdelidouFischer, 2010; Singh, Vinnicombe and Kumra, 2006) and 'professional women's networks' (e.g. Durbin, 2011; Gremmen and Benschop, 2011). For the sake of clarity and consistency, 
in this article we will refer to such networks as 'internal women-only networks' (IWONs). Meanwhile, an embryonic literature has acknowledged the development and importance of yet another formal networking opportunity: networks for women in business that are set up by women outside of organisations (McCarthy, 2004). In this article, we will refer to such networks as 'external women-only networks' (EWONs).

The development and continued existence of WONs suggests that, at the very least, there is demand for the resources that such formal networks potentially offer (Lawton-Smith et al., 2012). However, we know very little about the value that they can help to create. To date, most work on WONs is theoretical, qualitative or exploratory, and so formal WONs have yet to be assessed both quantitatively and qualitatively not only for their perceived or expected outcomes (e.g. O’Neil et al. 2011) but also for their actual impact (e.g. Bierema, 2005). The potential of both IWONs and EWONs thus deserves further scholarly attention. As a step in this direction, the next section builds on the emerging literature about IWONs and EWONs as well as on the broader social capital and network scholarship to develop propositions regarding the potential value of WONs for individual members, organisations and the wider social group of women in management and leadership positions.

\section{Women-Only Business Networks: Propositions development}

Although the phenomenon of IWONs and EWONs is relevant to both practitioners and research on women in organisations, the empirical and theoretical literature available about it is still rather limited. In light of this and in order to stimulate the theorisation and further empirical investigation of formal WONs, we develop a series of propositions below. We do this by combining the emerging literature on IWONs and EWONs with relevant work from the broader social capital and network scholarship.

\section{Networking in WONs}


As presented above, the prior literature has demonstrated the importance of networking for both men's and women's individual career development (e.g. Burt, 1998; Forret and Dougherty, 2004; Rasdi et al., 2013; Wolf and Moser, 2009). The broader literature also sheds light on the types of network ties that are more likely to lead to such individual-level career benefits. We generally find a distinction between expressive and instrumental ties and the resources accruing from them. Expressive ties are 'an end in themselves' and are considered important, for example, for obtaining emotional support and creating a sense of community (Umphress et al., 2003; Ibarra, 1992, 1993a, 1993b). In contrast, instrumental ties are 'goaloriented' and are thus deemed to be conducive to positive business or career outcomes (Casciaro et al., 2014). This suggests that expressive ties in business networks are less beneficial to career development than instrumental ones. Such a hierarchy is reflected in practice - for example, when IWON managers fear that the network may attract the 'wrong' participants, that is to say participants who are seeking chiefly emotional support rather than to exchange business- and career-oriented resources (Bierema, 2005; Singh et al., 2006).

However, studies of WONs provide a number of indications that the systematic distinction between and hierarchisation of expressive and instrumental ties is not necessarily as straightforward as expected. First, emotional support arising from expressive ties can be important for individual participants' performance and career progression. For instance, participants do consider psychological or emotional support as a key benefit of WONs (Singh et al., 2006) that can, for example, bolster self-confidence (McCarthy, 2004). WONs can thus be seen to provide opportunities to 'survive' in an organisation (McCarthy, 2004). This is vital, as elements such as a more inclusive climate or better mentoring opportunities can help women to thrive in the workplace (Krishnan, 2009; Stroh et al., 1996). Emotional support can also be combined with the career advice that network members provide to each other, and this 
combination can lead to instrumental value (Donnellon and Langowitz, 2009) even at a peerto-peer level (Kram and Isabella, 1985).

This suggests that a rigid distinction between and hierarchisation of instrumental and expressive ties is inappropriate in the case of WONs. On the contrary, it appears to be advantageous for WON members to make ties that lead to different types of resources, including emotional support. This is also time-savvy given the time constraints imposed by the heavier burden of home and family duties faced by women in a gendered society (Linehan, 2001; Sharafizad, 2011).

Moreover, we know that women are generally excluded from the informal networks through which information is shared that can be pivotal for career development (Singh et al., 2006). IWONs have been shown to help remedy this, for example by improving women's access to internal information about jobs and career opportunities (Pini et al., 2004; Singh et al., 2006).

Proposition 1: Participation in WONs grants women access to both expressive and instrumental resources, which in turn can foster career development.

Moreover, WONs provide opportunities for a sometimes disparate and scarce female management and leadership to come together and identify potential ties as well as mentors (Noe, 1988). Formal networks encourage higher-ranking women managers to display supportive behaviour towards more junior women in their organisation than in situations where only informal networking is available (Singh et al., 2006). This suggests that formal networks can mitigate what has been referred to as 'Queen Bee Syndrome' (Cohen et al., 1998; Rindfleish, 2000), whereby women in higher hierarchical positions tend to protect those positions by distancing themselves from other women.

In this context, and in line with our argument regarding Proposition 1, mentoring has been characterised as a combination of career guidance and psychological support (Noe, 1988). 
This is important, as mentoring is a crucial means of learning about behavioural norms and key success factors in a given context (Kram, 1985; McDonald and Westphal, 2013) and fostering skill development (Eby et al., 2008; Kram, 1985). Moreover, 'without a mentor, women often are unable to understand the reality of the male-dominated business culture and they fail to obtain the sponsorship needed to identify them as highly talented and to direct them in their career advancement' (Noe, 1988:p65). Mentoring is of particular interest to earlier-career women who can thus identify and meet more senior women and benefit from their experience (Pini et al., 2004). Senior members in WONs are also seen as role models who can inspire more women to strive for higher hierarchical positions (McCarthy, 2004) and share how they 'made it' despite adverse odds.

The possibility to develop a mentoring relationship with more senior women is important since women face gender-specific barriers to mentoring opportunities (Noe, 1988): as an 'out group' in management ranks, women have more difficulty in securing help from male managers, or 'in-group' members (Levine et al., 2005), in general, and one example of such help is mentoring (McDonald \& Westphal, 2013). In addition, it has been shown that because of stereotypes about relations between senior men and junior women, women can suffer from backlashes such as damaging gossip even when they succeed in establishing a mentoring relationship (Clawson and Kram, 1984). Finally, in the absence of formal structures, women tend not to approach women in higher hierarchical positions (Chow and $\mathrm{Ng}, 2007$ ). Overall, this suggests that formal WONs can be beneficial for more junior women managers.

Proposition 2: IWONs spur the development of junior-senior mentoring relationships between women managers, which in turn can foster career development for mentees.

However, IWONs are still found mostly in larger firms (Broadbridge, 2004), where such networks can bring together enough participants to create networking opportunities, that is to 
say create a suitable environment in which to forge new ties rather than merely duplicate existing work relations. In addition, given the overall scarcity of women in higher-ranking positions, SMEs are more likely to have very few of these and are thus unlikely to be able to offer formal networking opportunities (Lawton-Smith et al., 2012; McGowan et al., 2015), while in some industries even larger businesses employ too few women to develop formal WONs (Still and Timms, 2000). In cases such as these, women may not be interested in joining IWONs because they offer few opportunities for them to network with peers or more senior colleagues (Hersby et al., 2009, p. 426) and thus provide only scant opportunities to develop 'vertical' ties - that is, ties to more senior individuals - which are more likely to bring instrumental gains (Ibarra, 1993b).

Relative to IWONs, EWONs offer a potentially larger number of more senior members with whom to network, as they are open to women from different organisations and industries (McCarthy, 2004). This increases the chances of developing horizontal ties and, more importantly, vertical ties, which are conducive to instrumental gains such as knowledge or career opportunities (Ibarra, 1993b). This is an important characteristic, as senior women are interested in deriving instrumental resources from their networks (Durbin, 2011; Roomi, 2009) rather than developing solely expressive ties and/or providing support to more junior female managers. EWONs can thus provide an opportunity to further meet the networking needs of women in higher managerial and leadership positions as well as women in SMEs or other contexts in which there are too few female managers to develop IWONs.

Proposition 3: The more senior the woman manager and the smaller the number of women in senior positions in a firm or industry, the more attractive EWONs will be to make ties and access resources, which in turn can foster career development.

\section{From individual networks to organisational resources}


Beyond individual-level outcomes, the resources accruing from networks can include access to information and knowledge that can benefit organisations and ultimately have a positive impact on their performance (Koka and Prescott, 2002; Tsai, 2001; Uzzi, 1996). From the broader network literature, we also know that intra-organisational ties - compared to interorganisational ones - are more likely to bear characteristics such as trust and shared codes or mindsets (Nahapiet \& Ghoshal, 1998), that is to say to be 'strong' ties. Strong ties develop with time, as well as with emotional connection and intimacy (Granovetter, 1973), and are accordingly more easily nurtured in a context of high social embeddedness such as a focal organisation. Strong ties are more likely to facilitate access to privileged strategic information (Bouty, 2000; Wright, Van Wijk, \& Bouty, 1995). In addition, strong ties make complex knowledge exchanges easier and lead to a shared understanding of norms and codes (Hansen, 1999).

IWONs can thus establish conditions that help members to extract, codify and use their embedded knowledge and thereby help women to be included in knowledge exchange and creation in organisations (Durbin, 2011). They can therefore help information travel in focal organisations (Donnellon and Langowitz, 2009) and foster new patterns of connectivity (Pini et al., 2004). This helps develop a positive culture of knowledge sharing and creation in organisations (Cross and Armstrong, 2008).

This is in line with the fact that intra-organisational networks are known to create the conditions needed within organisations for cooperative knowledge exchange that can lead to non-threatening change (Josserand, 2004; Josserand and Villesèche, 2012; Wenger et al., 2002). The social capital literature corroborates this by underlining the importance of a horizontal (across departments) and vertical (across hierarchical levels) distribution of connections between actors in a single focal organisation in order to exchange and create 
knowledge that, in turn, can lead to positive organisational outcomes such increased organisational performance (Kostova \& Roth, 2003; Labianca \& Brass, 2006).

Proposition 4: IWONs improve patterns of inter-individual connectivity in organisations that favours information and knowledge circulation within the organisation, which in turn can enhance organisational performance.

However, the potential for heightened information and knowledge exchange through IWONs is limited by the very boundaries of the network. One key characteristic of intraorganisational networks is the fact that exchanges tend to be limited to the knowledge held by the members of the group, which 'results in the circulation of existing, less novel and routinebased knowledge, rather than new knowledge entering the system' (Makela et al., 2007, p. 14).

In contrast, it has been shown that organisations can leverage the more diverse, external networks of their managers to access external knowledge and information needed to create or sustain their competitive advantage (Collins and Clark, 2003). This is of strategic importance for organisations to avoid a lock-in situation, i.e. a situation where the incoming flow of information and other resources is insufficient to renew their resource base and strategic capabilities (Maurer \& Ebers, 2006; Afuah, 2000). Moreover, when a given individual is the unique contact point with another individual or organisation, this tie is called a 'bridging tie', because the individual is building a bridge over a structural hole (Burt, 1992). Such bridging ties are the most likely to give access to new information outside a focal group, such as a focal organisation (Burt, 1992; Granovetter, 1983). Structural holes thus increase the likelihood of accessing information diversity (Koka \& Prescott, 2002).

Individuals occupying such key network positions are also called 'brokers', and it is mainly through brokers that resources flow in and out of organisations (Aldrich and Herker, 1977; Perrone et al., 2003). The benefits that an organisation can gain from individual network development are well documented in the network and social capital literature, and include 
heightening the capacity to develop new partnerships (Gomes-Casseres et al., 2006) and reducing coordination costs in alliances (Yoshino and Lifson, 1986).

In line with this, it has been suggested employees should be encouraged to engage in external networks to develop external ties, and in particular bridging ties (Burt, 1992; Hansen, Podolny, \& Pfeffer, 2001). This is one way for managers to contribute to the development of organisational social capital (Andrews, 2010; Leana and Van Buren, 1999). EWONs represent one such opportunity for women managers. Gender homophily creates a basis for networking that sets EWON members apart from their male colleagues, and is thus likely to lead to a different set of ties and resources than male networks. It can also increase the chances of accessing resources of interest when these are identified, since actor similarity in networks is conducive to trust and reciprocity (Brass et al., 2004).

Proposition 5: Participation in EWONs can allow women managers to act as brokers by creating bridging ties that can lead to novel information and knowledge, which in turn can enhance organisational performance.

\section{Visibility, endurance, and advocacy}

Besides business objectives, networks emerge when certain interests are under-represented, such as in the case of women in business (Miller et al., 2007). Networks are also means through which actors can change their institutional environment (Beckert, 2010; Lawrence et al., 2002; Leblebici et al., 1991). Networks can offer a course of action characterised by collective agency (Keck and Sikkink, 1998). In collective agency, interdependent efforts are made to secure a goal for the collective (Bandura, 2000): the benefits accruing from collective agency help not only individual members but all members of the collective as a group, and possibly also individuals outside the network that are perceived as being part of the same social group. This underlines the collective potential of networks and is highly relevant here. Indeed, 'even when structural conditions produce gender difference and inequality, these are 
mediated through social interactions that always contain the potential for resistance' (Deutsch, 2007, p. 108).

However, the ability of WONs to collectively leverage such elements to actually improve women's standing in organisations is yet to be considered in the academic literature. We also know that agency in and through social networks is dependent on social context (Stevenson and Greenberg, 2000); this suggests that there are likely to be differences between EWONs and IWONs with regards to agential potential.

IWONs may be one of the building blocks for creating more gender-balanced organisations (McCarthy, 2004; SECO, 2010). They can help foster a collective identity among women of the same organisation based on shared goals and beliefs about how to improve women's standing in organisations (Pini et al., 2004). This can lead to 'a collective strategy in which the network becomes a vehicle for improving the status of women within organizations' (Hersby et al., 2009:p. 416). The very existence of IWONs can thus afford women and the issue of inequality greater visibility and can furnish women with a collective voice inside focal organisations (Singh et al 2006).

Proposition 6: At the organisational level, IWONs increase the visibility of the issues faced by women in business.

Beyond visibility is the question of change and advocacy. Besides the purpose of accessing and exchanging instrumental and emotional resources, women may decide to participate in IWONs because they feel that by doing so they can help change the 'gender status quo' in their organisation (Hersby et al., 2009) or, more broadly, contribute to the progress of a group with which they share a social identity (Hersby et al., 2009; Kaiser and Spalding, 2015).

One factor affecting the agential possibilities associated with IWONs is gender awareness. Some women join IWONs for the benefit of their own careers but without considering the 
importance of addressing issues collectively (Singh et al., 2006). This is directly connected to the agential potential of IWONs, since the level of gender awareness (i.e. awareness of gendered relations) is decisive in IWON members' ability to engage in advocacy work (Bierema, 2005).

In addition to individual gender awareness, IWONs' endurance and ability to fully develop depends on the level of managerial involvement and integration into the organisational culture (Donnellon and Langowitz, 2009). While some IWONs are created 'top-down', others can gradually garner support and formal sponsorship from the organisation's leadership, (Coleman, 2010; Donnellon and Langowitz, 2009). However, regardless of how they were created, when a firm's performance or activity level falls, IWONs are unfortunately deprioritised, leading to a fall in participation, or simply closed down (Donnellon and Langowitz, 2009). This can be explained by the fact that IWONs are generally not considered to be part of (and are even more rarely seen as central to) corporate strategy (Bierema, 2005) or organisational change initiatives (Hersby et al., 2009). Corporate leadership tends to consider IWONs to be aimed at solving issues for women among women (O'Neil et al., 2011). This is problematic, as voice and advocacy are developed only in the long term (Bierema, 2005; Hersby et al., 2009): the development of IWONs has been characterised as a process that takes time, with only the latter stages including elements such as the advancement of female staff and advocacy (Donnellon and Langowitz, 2009).

Proposition 7: The potential for IWONs to endure and foster advocacy is moderated by the gender awareness of their members and the level of organisational support that they receive.

By contrast, a study of EWONs in Germany and the UK shows that a significant proportion of their members joined with the intention of taking an 'activist's' stance (Avdelidou-Fischer and Kirton, 2015; Avdelidou-Fischer, 2012). As business networks, EWONs are targeted at 
an elite relative to the wider population. This does not tally with the dominant picture we find when thinking about feminist groups or grassroots social movements, that is to say groups exercising collective agency grounded in direct confrontation (Ferree and Martin, 1995). However, it does tally with the description of groups that want to foster change through collaboration rather than confrontation, often called 'new social movements' (O'Mahony and Bechky, 2008).

EWONs are thus seen to resist being categorised as feminist while nevertheless pursuing the rather feminist goals of women's advancement and equality (Avdelidou-Fischer and Kirton, 2015). Moreover, EWONs are independent networks whose members can decide network goals and activities, including the extent and scope of advocacy-oriented work (AvdelidouFischer, 2012; McCarthy, 2004).

Proposition 8: EWONs are more likely than IWONs to be a forum for advocacy work even in the early stages of their development due to their independent status as well as their members' comparatively higher motivation for activism.

\section{Concluding comments}

In this paper, we have reviewed the still limited scholarship on formal WONs. Using insights from the wider social capital and network literatures, we have developed propositions about how IWONs and EWONs can potentially yield benefits for their members but also for their organisations and for women in management and leadership positions more broadly. Below, we outline a number of suggestions of how our propositions could be taken up by scholars interested in this topic.

The first set of propositions (1-3) focused on how WONs can create value for individual members with regards to career development. In order to test such statements empirically, it would be useful to employ certain methods and scales used in scholarship on informal 
networks and their career-related outcomes. Output variables that have been used previously and would be relevant here include in particular those that are promotion-related (Burt, 1998; Forret and Dougherty, 2004) and income-related (Rasdi et al., 2013; Wolf and Moser, 2009). Other career development opportunities such as lateral moves to more prestigious or challenging positions (Lin and Dumin, 1986), external or international job offers (Linehan, 2001) and board appointments (Westphal and Stern, 2006) could also be of interest. When using networking as the explanatory variable, this could mean adapting and/or expanding the multidimensional scales developed by Forret and Dougherty (2004) or Wolf and Moser (2009) to measure networking behaviour. Finally, inspiration could be found in previous research on gender and the outcomes of mentoring (e.g. Eby et al., 2008; McDonald and Westphal, 2013).

The second set of propositions (4-5) suggests that WONs can create value not only for individuals but also for organisations and can help improve performance. The broader literature about networks, the resource-based view, or competitive advantage development contain a number of ideas for how to establish this link empirically. For example, Cowan and Jonard (2003; 2004) have looked at the interrelated dynamics of networks and knowledge dissemination with network analysis methods. Also on intra-organisational networks, Tsai (2001) looks at network centrality and how it impacts business unit performance; this could be of interest here as it could show which units or departments are affected by unfavourable network positions and how this can be related to the gender composition of groups and whether or not they participate in IWONs. Regarding the potential brokerage role of women managers, summary indexes such as that of 'network constraint' and 'indirect network constraint' developed by Burt (2007) may prove fruitful, as they offer the possibility of measuring whether an individual is in a position of brokerage and relate this to performance 
outcomes. Such a study should also compare women who are EWON members with ones who are not.

Finally, the third set of propositions (6-8) considers the broader societal impact that WONs could have. Assessing the increased visibility of women's issues in organisations as well as IWONs' advocacy potential could be achieved through longitudinal studies to compare the situation before and after the implementation of an IWON, or at different stages of its development. Such studies should not be limited to women's gender awareness (Bierema, 2005); they could be cross-sectional and compare IWONs across different industries and types of firm. With regards to advocacy in EWONs, research is also required to establish the efficiency and effectiveness of various forms of advocacy activities compared to more 'grassroots' or overtly feminist groups. Indeed, we can contend that women in senior positions have (so far) accepted the rules of the gendered organisations for which they work and are themselves exercising power over others, directly or symbolically. Hence, members of formal WONs can be considered part of a female elite produced by a specific type of training (Delamont, 1989). This potential replication of an exclusionary network dynamic should be further investigated in order to understand to what extent such networks may actually contribute to an improved gender balance in organisations more broadly.

We acknowledge that one of the limitations of our article and propositions is that they focus on the distinction that can be made between internal and external networks of this type. This means that we theoretically abstracted from other variations of interest, a decision also driven by the fact that the current body of literature on formal WONs still requires significant development in order to be theorised even more richly. Firstly, these networks are diverse beyond the internal-external dichotomy. Donnellon and Langowitz (2009) suggest that IWONs can exist as a single entity or have several national or international chapters in a multi-site corporation. Lawton and colleagues (2012) indicate that they can be differentiated 
on the basis of characteristics such as their target groups, sectors, functions or minimum hierarchical levels (some ask for a membership fee and/or propose different levels of membership), level of formalisation and spectrum of activity (e.g. specialist services vs. general introduction/facilitation). Along similar lines, Coleman (2010) discusses how EWONs can vary in size and level of formality, from those which are entirely voluntary to hierarchically organised networks with appointed or elected network officers.

Following such early efforts, it could be useful to develop an integrative typology venturing beyond the distinction between internal and external networks (Travers et al., 1997). Networks could then be compared in terms of the range of benefits they can confer, and specific member profiles could be explored. It would also be fruitful to examine their different aims and activities. Secondly, we need to learn more about how different types of WON may offer cumulative or different benefits. With this objective in mind, it would be useful to develop ethnographic studies that follow (shadow) a group of women managers from a focal firm in order to inductively spot and better understand individual or sub-group differences in aspirations, needs and perceived outcomes. We might also contrast the experiences of women who are members of both IWONs and EWONs and delve more deeply into differences between the experiences of junior and senior women managers.

In addition, we acknowledge that, since our objective is this paper was to review the existing literature about formal WONs and develop a set of testable propositions from this review, we have not questioned or discussed the (normative) assumptions that are made in the reviewed works. While in this article we demonstrate that there is a need for more scholarship and new thinking about WONs, we invite other researchers to complement our work with a critical review of the literature, including the conducting of an epistemological critique of the field. More broadly, we would also like to call for more ethnographic research - to counterbalance the current pre-eminence of interview-based or quantitative studies - as well as more critical 
research, which both have the potential to shed a different light on and open up new avenues for women's networking in business.

\section{Practical implications}

Even at this early stage of research into formal WONs, and despite the stringent need for further scholarship on the topic, a number of practical implications can be outlined. Firstly, organisations should be aware that insufficient support for and recognition of IWONs may deter participation and limit positive outcomes for both individuals and organisations. Vocal corporate support for such networks could also help signal a positive climate for workplace diversity, which can decrease turnover and attract diverse talent (Chrobot-Mason and Aramovich, 2013). EWONs should also be seriously considered as an opportunity for developing ties outside of one's organisation that are attainable through female brokers alone. On a related note, organisations that do not offer an IWON should encourage their staff to join EWONs to gain both emotional and instrumental support - for their own benefit and possibly also for that of their organisation. Finally, firms that do offer an IWON could see EWONs as a supplementary opportunity that can raise their employees' profiles as well as providing brokerage benefits. It is our hope that future research, taking our review and propositions as a starting point, will also help expand upon these practical implications.

\section{References}

Acker, J. (2006), "Inequality regimes - Gender, class, and race in organizations", Gender \& Society, Vol. 20 No. 4, pp. 441-464.

Aldrich, H. and Herker, D. (1977), "Boundary Spanning Roles and Organization Structure", The Academy of Management Review, Vol. 2 No. 2, pp. 217-230.

Andrews, R. (2010), “Organizational social capital, structure and performance”, Human Relations, Vol. 63 No. 5, pp. 583-608. 
Avdelidou-Fischer, N. (2012), "Career Obstacles, Discrimination and Women's Independent Networks: Evidence from the UK and Germany", in Wright, T. and Conley, H. (Eds.), Gower Handbook of Discrimination at Work, Gower Publishing, Burlington, pp. 83-96.

Avdelidou-Fischer, N. and Kirton, G. (2015), "Beyond burned bras and purple dungarees: Feminist orientations within working women's networks", European Journal of Women's Studies, online first.

Bandura, A. (2000), "Exercise of Human Agency Through Collective Efficacy", Current Directions in Psychological Science, Vol. 9 No. 3, pp. 75-78.

Beckert, J. (2010), "How Do Fields Change? The Interrelations of Institutions, Networks, and Cognition in the Dynamics of Markets", Organization Studies, Vol. 31 No. 5, pp. 605-627.

Bierema, L.L. (2005), "Women's Networks: A Career Development Intervention or Impediment?”, Human Resource Development International, Vol. 8 No. 2, pp. 207-224.

Bourdieu, P. 1986. (1986), "The Forms of Capital”, in Richardson, J.G. (Ed.), Handbook of theory and research for the sociology of education, Greenwood Press, New York, pp. 241258.

Brass, D.J. and Burkhardt, M.E. (1993), "Potential Power and Power Use: An Investigation of Structure and Behavior", The Academy of Management Journal, Vol. 36 No. 3, pp. 441-470.

Brass, D.J., Galaskiewicz, J., Greve, H.R. and Wenpin, T. (2004), "Taking stock of networks and organizations: a multilevel perspective", Academy of Management Journal, Vol. 47 No. 6, pp. $795-817$.

Broadbridge, A. (2004), "It's not what you know, it's who you know", Journal of Management Development, Vol. 23 No. 6, pp. 551-562.

Burt, R.S. (1992), Structural holes. The Social Structure of Competition, Harvard University Press, Cambridge, MA.

Burt, R.S. (1998), “The gender of social capital”, Rationality and Society, Vol. 10 No. 1, pp. $5-46$.

Burt, Ronald S. (2007), "Secondhand brokerage: Evidence on the importance of local structure for managers, bankers, and analysts", Academy of Management Journal Vol. 50, No. 1, pp. 119-148.

Casciaro, T., Gino, F. and Kouchaki, M. (2014), "The Contaminating Effects of Building Instrumental Ties: How Networking Can Make Us Feel Dirty", Administrative Science Quarterly, Vol. 59 No. 4, pp. 705-735.

Chow, I.H.S. and Ng, I. (2007), "Does the gender of the manager affect who he/she networks with?”, Journal of Applied Business Research, Vol. 23 No. 4, pp. 49-60.

Chrobot-Mason, D. and Aramovich, N.P. (2013), "The Psychological Benefits of Creating an Affirming Climate for Workplace Diversity", Group \& Organization Management, Vol. 38 No. 6, pp. 659-689.

Clawson, J.G. and Kram, K.E. (1984), "Managing Cross-Gender Mentoring", Business Horizons, No. May-June, pp. 22-32. 
Cohen, L., Broschak, J. and Haveman, H. (1998), "And Then There Were More? The Effect of Organizational Sex Composition on the Hiring and Promotion of Managers", American Sociological Review, Vol. 63 No. 5, pp. 711-727.

Coleman, M. (2010), "Women-only (homophilous) networks supporting women leaders in education”, (Sherman, W.H., Ed.), Journal of Educational Administration, Vol. 48 No. 6, pp. 769-781.

Collins, C.J. and Clark, K.D. (2003), "Strategic human resource practices, top management team social networks, and firm performance: the role of human resource practices in creating organizational competitive advantage", Academy of Management Journal, Vol. 46 No. 6, pp. 740-751.

Cross, C. and Armstrong, C. (2008), "Understanding the role of networks in collective learning processes: The experiences of women", Advances in developing human resources, Vol. 10 No. 4, pp. 600-613.

Dawson, C., Fuller-Love, N., Sinnott, E. and O'Gorman, B. (2011), "Entrepreneurs' perceptions of business networks: does gender matter?", The International Journal of Entrepreneurship and Innovation, Vol. 12 No. 4, pp. 271-281.

Delamont, S. (1989), Knowledgeable women: Structuralism and the reproduction of elites, Routledge, London.

Deutsch, F.M. (2007), “Undoing Gender”, Gender \& Society, Vol. 21 No. 1, pp. 106-127.

Donnellon, A. and Langowitz, N. (2009), "Leveraging women's networks for strategic value", Strategy \& Leadership, Vol. 37 No. 3, pp. 29-36.

Dries, N. and Pepermans, R. (2007), “Real' high-potential careers", Personnel Review, Vol. 37 No. 1, pp. 85-108.

Durbin, S. (2011), "Creating Knowledge through Networks: a Gender Perspective", Gender, Work and Organization, Vol. 18 No. 1, pp. 90-112.

Eby, L.T., Allen, T.D., Evans, S.C., Ng, T. and DuBois, D.L. (2008), "Does mentoring matter? A multidisciplinary meta-analysis comparing mentored and non-mentored individuals", Journal of Vocational Behavior, Vol. 72 No. 2, pp. 254-267.

Ferree, M.M. and Martin, P.Y. (1995), Feminist organizations: harvest of the new women's movement, Temple University Press, Philadelphia.

Forret, M.L. and Dougherty, T.W. (2004), "Networking behaviors and career outcomes: differences for men and women?", Journal of Organizational Behavior, Vol. 25, pp. 419-437.

Gamba, M. and Kleiner, B.H. (2001), “The old boys' network today", International Journal of Sociology and Social Policy, Vol. 21 No. 8/9/10, pp. 101-107.

Gomes-Casseres, B., Hagedoorn, J. and Jaffe, A.B. (2006), "Do alliances promote knowledge flows?”, Journal of Financial Economics, Vol. 80 No. 1, pp. 5-33.

Granovetter, M.S. (1983), "The Strength of Weak Ties: A Network Theory Revisited", Sociological Theory, Vol. 1, pp. 201-233. 
Groysberg, B. and Bell, D. (2013), "Dysfunction in the Boardroom", Harvard Business Review, Vol. 91 No. 6, pp. 88-97.

Hansen, M.T. (1999), "The Search-Transfer Problem: The Role of Weak Ties in Sharing Knowledge across Organization Subunits”, Administrative Science Quarterly, Vol. 44, pp. 82-111.

Hansen, M.T., Podolny, J.M. and Pfeffer, J. (2001), "So many ties, so little time: A task contingency perspective on corporate social capital in organizations", Research in the Sociology of Organizations, Elsevier, Vol. 18, pp. 21-57.

Hersby, M.D., Ryan, M.K. and Jetten, J. (2009), "Getting Together to Get Ahead: The Impact of Social Structure on Women's Networking”, British Journal of Management, Vol. 20 No. 4, pp. 415-430.

Ibarra, H. (1992), "Homophily and Differential Returns: Sex Differences in Network Structure and Access in an Advertising Firm", Administrative Science Quarterly, Vol. 37 No. 3, pp. 422-447.

Ibarra, H. (1993a), "Network Centrality, Power, and Innovation Involvement: Determinants of Technical and Administrative Roles", The Academy of Management Journal, Vol. 36 No. 3, pp. 471-501.

Ibarra, H. (1993b), "Personal Networks of Women and Minorities in Management: A Conceptual Framework", The Academy of Management Review, Vol. 18 No. 1, pp. 56-87.

Josserand, E. (2004), The network organization: the experience of leading French multinationals, E. Elgar Pub., Cheltenham, UK.

Josserand, E. and Villesèche, F. (2012), "Communities of practice: from innovation in practice to the practice of innovation", in Pitsis, T.S., Simpson, A. and Dehlin, E. (Eds.), Handbook of Organizational and Managerial Innovation, Edward Elgar, Cheltenham, UK, pp. 256-274.

Kaiser, C.R. and Spalding, K.E. (2015), "Do women who succeed in male-dominated domains help other women? The moderating role of gender identification", European Journal of Social Psychology, Vol. 45 No. 5, pp. 599-608.

Keck, M.E. and Sikkink, K. (1998), Activists beyond borders: advocacy networks in international politics, Cornell University Press, Ithaca, N.Y.

Kogut, B., Colomer, J. and Belinky, M. (2014), "Structural equality at the top of the corporation: Mandated quotas for women directors", Strategic Management Journal, Vol. 35 No. 6, pp. 891-902.

Koka, B.R. and Prescott, J.E. (2002), "Strategic alliances as social capital: a multidimensional view”, Strategic Management Journal, Vol. 23 No. 9, pp. 795-816.

Kostova, T. and Roth, K. (2003), "Social Capital in Multinational Corporations and a MicroMacro Model of Its Formation", Academy of Management Review, Vol. 28 No. 2, pp. 297317.

Kram, K.E. (1985), Mentoring at work: developmental relationships in organizational life, Scott Foresman. 
Kram, K.E. and Isabella, L.A. (1985), "Mentoring alternatives: The role of peer relationships in career development", Academy of Management Journal, pp. 110-132.

Krishnan, H.A. (2009), "What causes turnover among women on top management teams?", Journal of Business Research, Vol. 62 No. 11, pp. 1181-1186.

Kumra, S. and Vinnicombe, S. (2010), "Impressing for Success: A Gendered Analysis of a Key Social Capital Accumulation Strategy", Gender, Work \& Organization, Vol. 17 No. 5, pp. 521-546.

Labianca, G. and Brass, D.J. (2006), "Exploring the social ledger: negative relationships and negative asymmetry in social networks in organizations", Academy of Management Review, Vol. 31, pp. 596-614.

Lawrence, T.B., Hardy, C. and Nelson, P. (2002), "Institutional Effects of Interorganizational Collaboration: The Emergence of Proto-Institutions", The Academy of Management Journal, Vol. 45 No. 1, pp. 281-290.

Lawton-Smith, H., Romeo, S. and Virahsawmy, M. (2012), "Business and professional networks: Scope and outcomes in Oxfordshire", Environment and Planning, Vol. 44 No. 8, pp. 1801-1818.

Leana, C.R. and Van Buren, H.J. (1999), "Organizational social capital and employment practices", Academy of management review, Academy of Management, Vol. 24 No. 3, pp. $538-555$.

Leblebici, H., Salancik, G.R., Copay, A. and King, T. (1991), "Institutional Change and the Transformation of Interorganizational Fields: An Organizational History of the U . S . Radio Broadcasting Industry", Administrative Science Quarterly, Vol. 36 No. 3, pp. 333-363.

Levine, M., Prosser, A., Evans, D. and Reicher, S. (2005), "Identity and emergency intervention: How social group membership and inclusiveness of group boundaries shape helping behavior", Personality and Social Psychology Bulletin, Vol. 31 No. 4, pp. 443-453.

Lin, N. and Dumin, M. (1986), "Access to occupations through social ties", Social Networks, Vol. 8 No. 4, pp. 365-385.

Linehan, M. (2001), "Networking for female managers' career development", Journal of Management Development, Vol. 20 No. 10, pp. 823-829.

Makela, K., Kalla, H.K. and Piekkari, R. (2007), "Interpersonal similarity as a driver of knowledge sharing within multinational corporations", International Business Review, Vol. 16 No. 1, pp. 1-22.

Maurer, I. and Ebers, M. (2006), "Dynamics of Social Capital and Their Performance Implications: Lessons from Biotechnology Start-ups", Administrative Science Quarterly, Vol. 51 No. 2, pp. 262-292.

McCarthy, H. (2004), Girlfriends in High Places - How women's networks are changing the workplace, London: Demos.

McDonald, M.L. and Westphal, J.D. (2013), “Access Denied: Low Mentoring of Women and Minority First-Time Directors and its Negative Effects on Appointments To Additional Boards", Academy of Management Journal, Vol. 56 No. 4, pp. 1169-1198. 
McGowan, P., Cooper, S., Durkin, M. and O'Kane, C. (2015), "The Influence of Social and Human Capital in Developing Young Women as Entrepreneurial Business Leaders", Journal of Small Business Management, Vol. 53 No. 3, pp. 645-661.

McGuire, G.M. (2000), "Gender, Race, Ethnicity, and Networks: The Factors Affecting the Status of Employees' Network Members”, Work and Occupations, Vol. 27 No. 4, pp. 501524.

McPherson, M., Smith-Lovin, L. and Cook, J.M. (2001), "Birds of a feather: Homophily in social networks”, Annual Review of Sociology, Vol. 27, pp. 415-444.

Miller, N.J., Besser, T.L. and Riibe, J. V. (2007), "Do strategic business networks benefit male- and female-owned small-community businesses?", Journal of small business strategy, Vol. 17 No. 2, p. 53.

Noe, R.A. (1988), "Women and Mentoring: A Review and Research Agenda", Academy of Management Review, Vol. 13 No. 1, pp. 65-78.

O’Mahony, S. and Bechky, B.A. (2008), "Boundary Organizations: Enabling Collaboration among Unexpected Allies”, Administrative Science Quarterly, Vol. 53 No. 3, pp. 422-459.

O’Neil, D. a., Hopkins, M.M. and Sullivan, S.E. (2011), "Do women's networks help advance women's careers? Differences in perceptions of female workers and top leadership", Career Development International, Vol. 16 No. 7, pp. 733-754.

Perrone, V., Zaheer, A. and McEvily, B. (2003), "Free to Be Trusted? Organizational Constraints on Trust in Boundary Spanners", Organization Science, Vol. 14 No. 4, pp. 422 439.

Pini, B., Brown, K. and Ryan, C. (2004), "Women-only networks as a strategy for change? A case study from local government", Women in Management Review, Vol. 19 No. 6, pp. 286292.

Rasdi, R.M., Garavan, T.N. and Ismail, M. (2013), "Networking behaviours and managers' career success in the Malaysian public service", Personnel Review, Vol. 42 No. 6, pp. 684703.

Rindfleish, J. (2000), "Senior management women in Australia: diverse perspectives", Women In Management Review, Vol. 15 No. 4, pp. 172-183.

Roomi, M.A. (2009), "Impact of social capital development and use in the growth process of women-owned firms", Journal of Enterprising Culture, Vol. 17 No. 04, pp. 473-495.

Rutherford, S. (2001), "Organizational cultures, women managers and exclusion”, Women in Management Review, Vol. 16 No. 8, pp. 371-382.

SECO. (2010), Les femmes dans des fonctions dirigeantes: les clés de la réussite, Bern.

Sharafizad, J. (2011), "Determinants of business networking behaviour of women in small businesses", Small Enterprise Research, Vol. 18 No. 2, pp. 158-160.

Singh, V., Vinnicombe, S. and Kumra, S. (2006), "Women in formal corporate networks: an organisational citizenship perspective", Women in Management Review, Vol. 21 No. 6, pp. $458-482$. 
Stevenson, W.B. and Greenberg, D. (2000), "Agency and Social Networks: Strategies of Action in a Social Structure of Position, Opposition, and Opportunity", Administrative Science Quarterly, Vol. 45 No. 4, pp. 651-678.

Still, L. V. and Timms, W. (2000), "Women's business: the flexible alternative workstyle for women”, Women in Management Review, Vol. 15 No. 5/6, pp. 272-283.

Stroh, L.K., Brett, J.M. and Reilly, A.H. (1996), "Family Structure, Glass Ceiling, and Traditional Explanations for the Differential Rate of Turnover of Female and Male Managers", Journal of Vocational Behavior, Vol. 49 No. 1, pp. 99-118.

Timberlake, S. (2005), "Social capital and gender in the workplace", Journal of Management Development, Vol. 24 No. 1, pp. 34-44.

Travers, C., Pemberton, C. and Stevens, S. (1997), "Women's networking across boundaries: recognizing different", Women In Management Review, Vol. 12 No. 2, pp. 61-67.

Tsai, W. (2001), "Knowledge Transfer in Intraorganizational Networks: Effects of Network Position and Absorptive Capacity on Business Unit Innovation and Performance", Academy of Management Journal, Vol. 44 No. 5, pp. 996-1004.

Umphress, E.E., Labianca, G., Brass, D.J., Kass, E. and Scholten, L. (2003), “The Role of Instrumental and Expressive Social Ties in Employees' Perceptions of Organizational Justice", Organization Science, Vol. 14 No. 6, pp. 738-753.

Uzzi, B. (1996), "The Sources and Consequences of Embeddedness for the Economic Performance of Organizations: The Network Effect", American Sociological Review, Vol. 61 No. 4, pp. 674-698.

Wenger, E., McDermott, R.A. and Snyder, W. (2002), Cultivating communities of practice: a guide to managing knowledge, Harvard Business School Press, Boston, MA.

Westphal, J.D. and Milton, L.P. (2000), "How Experience and Network Ties Affect the Influence of Demographic Minorities on Corporate Boards", Administrative Science Quarterly, Vol. 45 No. 2, pp. 366-398.

Westphal, J.D. and Stern, I. (2006), "The Other Pathway to the Boardroom: Interpersonal Influence Behavior as a Substitute for Elite Credentials and Majority Status in Obtaining Board Appointments", Administrative Science Quarterly, Vol. 51 No. 2, pp. 169-204.

Wilson, E.M. (1998), “Gendered career paths”, Personnel Review, Vol. 27 No. 5, pp. 396411.

Wilson, E.M. (2000), "Inclusion, exclusion and ambiguity - The role of organisational culture", Personnel Review, Vol. 29 No. 3, pp. 274-303.

Wilson, P. (1991), "Women Employees and Senior Management", Personnel Review, Emerald, Vol. 20 No. 1, pp. 32-36.

Wolff, H.-G. and Moser, K. (2009), "Effects of networking on career success: a longitudinal study.", The Journal of applied psychology, Vol. 94 No. 1, pp. 196-206.

Yoshino, M.Y. and Lifson, T.B. (1986), The invisible link, MIT Press. 